\title{
Modulation of Estrogen $\alpha$ and Progesterone Receptors in Triple Negative Breast Cancer Cell Lines: The Effects of Vorinostat and Indole-3-Carbinol In Vitro
}

\author{
FATEMEH NOURIEMAMZADEN ${ }^{1}$, BEVERLY WORD $^{1}$, EBONY COTTON $^{1}$, \\ ANFERNEE HAWKINS ${ }^{1}$, KAI LITTLEJOHN ${ }^{1}$, RHONDA MOORE ${ }^{2}$, \\ GUSTAV MIRANDA-CARBON ${ }^{3}$, CHINNA NNEKA ORISH ${ }^{4}$ and BEVERLY LYN-COOK ${ }^{1}$ \\ ${ }^{1}$ Division of Biochemical Toxicology, FDA/NCTR, Jefferson, AR, U.S.A.; \\ ${ }^{2}$ Division of Nonprescription Drugs, FDA/Center for Drug Evaluation Research, White Oak, MD, U.S.A.; \\ ${ }^{3}$ Division of Hematology-Oncology, University of Tennessee Health Science Center, Memphis, TN, U.S.A.; \\ ${ }^{4}$ Department of Anatomy, Faculty of Basic Medical Sciences, University of Port-Harcourt, Port Harcourt, Nigeria
}

\begin{abstract}
Background/Aim: Triple negative cancer (TNBC) is a subtype of breast cancer that is highly aggressive, with poor prognosis and responds differently to treatments. This study investigated the role of vorinostat and indole-3carbinol (I3C) on regulating critical receptors that are not normally expressed in TNBC. Materials and Methods: Using real-time PCR, immunostaining, and western blots, the reexpression of estrogen receptor $\alpha(E R)$, progesterone receptor $(P R)$ and human epidermal growth factor receptor2 (HER2) receptors was examined in four different TNBC cell types. Results: ER $\alpha$ was re-expressed in three subtypes using vorinostat and I3C. Re-expression of the $P R$ by vorinostat was also detected. Neither vorinostat nor I3C resulted in re-expression of the HER2 receptor. A significant decrease in growth and sensitivity to tamoxifen was also noted. Conclusion: The results of this study show that vorinostat and I3C modulate the re-expression of critical receptors in certain subtypes of TNBC through several pathways and these effects can be influenced by the molecular profiles of TNBCs.
\end{abstract}

This article is freely accessible online.

Disclaimer: The views presented in this manuscript do not necessarily reflect those of the US Food and Drug Administration.

Correspondence to: Beverly D. Lyn-Cook, Division of Biochemical Toxicology, HFT-100, FDA/National Center for Toxicological Research, Jefferson, AR 70729, U.S.A. Tel: +1 8705437965, Fax: +18705439019, e-mail: Beverly.lyn-cook@fda.hhs.gov

Key Words: Vorinostat, I3C, triple negative breast cancer, estrogen receptor, progesterone receptor, HDAC activity, HDAC7.
Triple negative breast cancer (TNBC) is one of the most aggressive subtypes of breast cancer (1). Although about $85 \%$ of breast cancers are estrogen-positive, about $15-20 \%$ fall into the category of TNBC. This subtype of cancer lacks targeted therapy receptors, such as the estrogen receptor $(\mathrm{ER})$, the progesterone receptor (PR), and the human epidermal growth factor receptor-2 (HER2) (2). The estrogen receptor status is important, both as an independent indicator of prognosis and as a basis for selecting a treatment. Specifically, patients whose tumors are characterized as ERpositive are candidates for anti-estrogen therapy, such as tamoxifen (or similar agents), while patients with ERnegative tumors are often given cytotoxic chemotherapy as a standard of care (2). In addition to estrogen's role in breast cancer, a recent study (3) examined the role of progesterone in TNBC and recurring TNBC tumors that often have a tendency to develop resistance to current therapeutics. TNBC patients are often limited to cytotoxic chemotherapies with harsh side effects. In addition, this type of cancer has the tendency to occur in younger women and is associated with risk factors, including: i) being of African descent (4), ii) BRCA1 mutation (5-7), iii) a strong family history of breast cancer (8), iv) lifestyle, and v) environmental factors (9-11). Additional risk factors involving life-style include: i) poor diet $(12,13)$, ii) high alcohol intake $(14,15)$, iii) smoking $(16,17)$, iv) lack of breastfeeding $(18,19)$, v) lack of exercise (20), and vi) obesity. Although mutations in BRCA 1 and 2 are known to be involved in the initiation of TNBC (21-25), research has revealed that these genes are regulated by epigenetic factors $(26,27)$. A number of environmental and lifestyle-related factors can contribute to the modulation of receptors' expression that are involved in signaling pathways through epigenetic mechanisms (28). The modification of histones is a known epigenetic mechanism 
involved in the regulation of gene expression. Acetylation is associated with gene expression while deacetylation is associated with gene repression (29).

In cancer certain epigenetic modifications may result in reversible changes in gene expression of critical signaling pathways. Targeting the mechanisms that control such epigenetic modifications could potentially be used in cancer therapy $(29,30)$. Considerable interest has developed with regards to understanding the role of histone deacetylases (HDACs) in cancer. HDACs are part of a superfamily that is divided into different classes based on their mode of action (31), such as i) cancer progression (32), ii) self-renewal and expansion of stem cells (33), and iii) epithelial to mesenchymal transition (EMT) (34). Although studies have also shown that inactivation of certain HDACs may be involved in tumorigeneses (35), increased HDAC activity has been noted in a number of cancers $(36,37)$, including TNBC (38). HDACs are involved in a number of cellular events in cancer, such as i) tissue differentiation (39), ii) autophagy (40), iii) apoptosis (41), iv) migration (42), and v) mitosis (39). These enzymes deacetylate histone and nonhistone proteins (41) and are involved in the regulation of the cell cycle (42), DNA damage response and autophagy (43), metastasis, and angiogenesis (44).

Epigenetic drugs, such as histone deacetylases inhibitors (HDACis), are emerging as promising therapies for various cancers, including TNBC. Because of their ability to target different pathways, HDACis are known as multifunctional agents. Inhibition of certain HDACs has been associated with the induction of apoptosis and cell cycle arrest (45). Recently, studies showed that HDACis, such as vorinostat, modulate critical HDACs involved in cancer stem cell progression, such as increases in HDAC7, which is also associated with poor prognosis (46). Studies have also shown the ability of HDACi to re-express critical genes producing tumor suppressors (47) and critical receptors, such as ER $\alpha$ in TNBC (48).

Progesterone $(\mathrm{P})$ is also known to suppress TNBC cells (49). Progesterone plays an important role in mammary epithelial cell proliferation by binding to its receptor (PR), followed by receptor dimerization, nuclear localization, and binding to progesterone-responsive elements in target genes (50). High levels of progesterone are considered a risk for breast cancer under certain conditions (51), with a yet unidentified role in TNBC. However, studies have shown that progesterone- $\alpha$ receptors are expressed in TNBC and that progesterone suppresses growth and invasion of tumors or TNBC cells expressing high levels of progesterone- $\alpha$ receptors (52).

The lack of expression of HER-2 is another feature of TNBC (53). Excessive expression of HER-2 stimulates cell growth (54). Drugs targeting the HER-2 protein, such as Herceptin (trastuzumab), are given to patients with HER-2 positive breast cancer (55), but these do not have any effect on TNBC patients. To date, no drug is known to re-express HER-2 in TNBC.

Improvement on the treatment of women with TNBC is greatly needed. These cancers are very invasive and the associated mortality rate is extremely high, affecting also women under 40, during their reproductive years (1). Understanding whether ER, PR, or HER2 receptors can be reactivated in specific subtypes will greatly enhance our understanding of epigenetic regulation in these highly deadly cancers and can, thus, expand the treatment potential of the currently approved targeted therapies for these subtypes of TNBC. This study investigated the role of epigenetic mechanisms controlling the re-expression of major drug targeting receptors (ER, PR, and HER-2) in TNBC subtypes. The effect of treatments using vorinostat as an epigenetic drug and indole-3-carbinol as a dietary agent were assessed alone or in combination in cells representing different TNBC subtypes to determine if re-expressing critical receptors could increase the cells' sensitivity to targeted therapies.

\section{Materials and Methods}

Chemicals, drugs and antibodies. Vorinostat, 4-hydroxytamoxifen, and indole-3-carbinol (I3C) were purchased from Sigma-Aldrich (St. Louis, MO, USA). Estrogen (17- $\beta$ estradiol) was purchased from Sigma-Aldrich. MTS kits (Cell Titer 96 Cell Proliferation Assay) were purchased from Promega (Madison, WI, USA). BioCoat Invasion chambers were purchased from Thermo Fisher Scientific (Waltham, MA, USA).

Cell lines and treatment. MDA-MB-231, HCC70, HCC1806, BT549, HCC1143, and MCF7 cells were purchased from American Type Culture Collection (Manassas, VA, USA). IC50s were determined for vorinostat in the triple-negative cell lines MDA-MB231 (ATCC ${ }^{\circledR}$ HTB-26 ${ }^{\mathrm{TM}}$ ) (M: Mesenchymal stem cell-like), BT-549 (ATCC ${ }^{\circledR}$ HTB-122 $^{\mathrm{TM}}$ ) (M: mesenchymal-like), HCC1806 (ATCC ${ }^{\circledR}$ CRL-2335 ${ }^{\mathrm{TM}}$ ) and HCC70 (ATCC ${ }^{\circledR}$ CRL-2315 ${ }^{\mathrm{TM}}$ ) are both basallike (BL2), HCC 1143 (ATCC ${ }^{\circledR}$ CRL-2321 ${ }^{\mathrm{TM}}$ ), and the breast cancer cell line MCF7 (ATCC ${ }^{\circledR}$ HTB-22 ${ }^{\mathrm{TM}}$ ) . BT549, MB-231, MCF10A (ATCC ${ }^{\circledR}$ CRL-1037 ${ }^{\mathrm{TM}}$ ) and MCF7 cells were grown in GIBCO MEM media (Thermo Fisher Scientific) supplemented with fetal bovine serum, L-glutamine, and penicillin-streptomycin. HCC70 cells were grown in GIBCO RPMI media (Thermo Fisher Scientific) supplemented with fetal bovine serum (Atlanta Biologicals-Premium select, Minneapolis, MN, USA), HEPES buffer, pen strep, sodium pyruvate, and L-glutamine (all purchased from Life Technologies, Carlsbad, CA, USA). HCC1806 and HCC1143 cells were grown in RPMI media supplemented with pen strep and L-glutamine. For the treatment, all cell lines were grown in phenol-free, charcoal-stripped serum (Atlanta BiologicalPremium select, Minneapolis, MN, USA) for 3-5 days prior to treatment with $17-\beta$-estradiol $(100 \mathrm{nM})$, vorinostat (both from Sigma-Aldrich, St. Louis, MO, USA) $(10 \mu \mathrm{M})$ (doses were determined from a dose range study and $\left.\mathrm{IC}_{50}\right)$, or $\mathrm{I} 3 \mathrm{C}(300 \mu \mathrm{M})$. For all studies discussed in this manuscript, cells were exposed to treatment agents for $24 \mathrm{~h}$. Whole cell lysates, DNA and total RNA were collected after $6,12,24$, and $48 \mathrm{~h}$ of treatment. 
mRNA. Total RNA was extracted using the Qiagen RNeasy Micro kit (QIAGEN, Germantown, MD, USA) and cDNA was synthesized using SuperScript III (Bio-Rad Laboratories, Hercules, CA, USA). The expression levels of mRNA were measured using TaqMan ${ }^{\circledR}$ Gene Expression arrays for ER $\alpha$, PR, HER2 and $\beta$-actin. Real Time PCR was run with the QuantStudio system from Thermo Fisher Scientific. Results were analyzed using Applied Biosystems qPCR Analysis Module within the Thermo Fisher Cloud.

Immunostaining (ER and $P R$ ). All cells were grown in 24-well plates (Thermo Fisher Scientific). Cells were seeded and treated with the drugs, vorinostat, 17- $\beta$-estradiol or I3C. Following treatment, the cells were washed with phosphate-buffered saline (PBS) and fixed with $4 \%$ paraformaldehyde for $10 \mathrm{~min}$ at room temperature. Then the cells were permeabilized with $0.2 \%$ Triton X-100TM Surfact-AmpsTM Detergent Solution (Thermo Fisher Scientific; Catalog number: 85111) for $10 \mathrm{~min}$ at room temperature, followed by washing with ice-cold PBS. To block unspecific antigen epitopes, the cells were blocked with cold fish serum (Thermo Fisher Scientific; Catalog number: 37527$)$ for $1 \mathrm{~h}$ at room temperature. Subsequently, cells were incubated with a primary antibody [monoclonal anti-ER alpha (Abcam, Cambridge, MA, USA)] in 1\% fish serum overnight on a shaker at $4{ }^{\circ} \mathrm{C}$. The cells were washed 3 times with PBS-T20 (Pierce 20X PBS Tween-20, diluted to $1 \mathrm{X}$ with water which contains $10 \mathrm{mM}$ sodium phosphate, $0.15 \mathrm{M} \mathrm{NaCl}, 0.05 \%$ Tween $^{\mathrm{TM}} 20, \mathrm{pH} 7.5$, (Thermo Fisher Scientific; Catalog number 28352) 10 min each time and incubated with a secondary antibody [goat polyclonal secondary antibody to Rabbit IgG-H\&L (Alexa Fluor ${ }^{\circledR}$ 555), ab150078 (Abcam)] in $1 \%$ cold fish serum in the dark for $30 \mathrm{~min}$ at $37^{\circ} \mathrm{C}$ on a shaker. Cells were washed three times with PBS-T20 for 10 min each time and then the nuclei were stained using DAPI [NucBlue ${ }^{\mathrm{TM}}$ Live ReadyProbes $^{\mathrm{TM}}$ Reagent, Catalog number: R37605, (Thermo Fisher Scientific)] for $5 \mathrm{~min}$ before taking images.

MTS assay. Cancer cells from each subtype were plated in 96-well plates $(10,000$ cells per well) and were treated with vorinostat (10 $\mu \mathrm{M})$ for $1,3,5$, and 7 days. Procedures were followed as outlined in the MTS protocol (Promega, Madison, WI, USA).

Cell migration and invasion assay. To determine the invasive potential of the TNBC cell lines before and after each treatment, cells were evaluated using the BD Biocoat ${ }^{\mathrm{TM}}$ Matrigel $^{\mathrm{TM}}$ Invasion Chambers (BD Biosciences, San Jose, CA, USA; Catalog Number 354480). Each cell culture invasion chamber contains an 8-micron pore size PET membrane treated with Matrigel Matrix. An appropriate number of TNBC cells $(10,000)$ per invasion chamber was seeded in the presence or absence of each treatment. The medium in the upper chamber was serum-free, while the medium in the lower chamber contained 5\% FBS as a chemoattractant. Noninvasive cells were removed with a cotton swab and cells that migrated through the Matrigel Matrix were stained on the lower surface of the membrane with toluidine stain (Thermo Fisher Scientific) and scored for\% invasion or inhibition of invasion.

Protein. Whole cell protein lysates were prepared using RIPA lysis buffer (Thermo Fisher Scientific). Total protein (40 $\mu \mathrm{g} / \mathrm{lane})$ was separated using Bolt 4-12\% Bis-Tris precast gels (Life Technologies) in Bolt MES and were transferred onto PDF membranes using the iBlot Dry Blotting system (Thermo Fisher Scientific). Western blot analysis was performed using the iBind Western Blot System
(Thermo Fisher Scientific) with two primary antibodies: i) rabbit monoclonal anti-ER alpha antibody, and ii) rabbit polyclonal anti- $\alpha$ tubulin (ab52866), 1:6000, and a secondary anti-rabbit HRPconjugated antibody (both from Abcam). Protein levels were detected using Supersignal West Femto (Thermo Fisher Scientific) and the ChemiDoc Touch Imaging System (Bio-Rad). Images were analyzed using the Image Lab 6.0.1 software (Bio-Rad).

Nuclear extraction and HDAC total activity. EpiQuik ${ }^{\mathrm{TM}}$ nuclear extraction kits (Epigentek, Farmingdale, NY, USA) were used on the treated cells to assess the HDAC activity. Procedures were followed according to the manufacturers' instructions. The Epigenase $^{\mathrm{TM}}$ HDAC Activity/Inhibition Direct assay kit (Epigentek) was used for the measurement of the HDAC activity/inhibition. Briefly, in this assay an acetylated histone HDAC substrate is stably coated onto microplate wells. Active HDACs bind to the substrate and remove acetyl groups from it. The HDAC-deacetylated products can be recognized using a high affinity acetylated HDAC histone capture-antibody provided in the kit. The ratio or amount of deacetylated products, which is proportional to the enzyme activity, can then be colorimetrically measured using a Cytation 3 cell imaging reader (BioTek Instruments, Winooski, VT, USA) and reading at $450 \mathrm{~nm}$. The activity of the HDAC enzyme is proportional to the OD intensity measured.

Statistical analyses. One-way ANOVA analyses were performed using the Prism software Version 6.0 (GraphPad, San Diego, CA, USA). To compare values, $p$-Values of $<0.05$ were considered significant. Graphs represent the mean $\pm \mathrm{SD}$.

\section{Results}

Re-expression of ER $\alpha$ and $P R$ receptors ( $R N A$ and immunostaining). We investigated the effects of the smallmolecule vorinostat (V), also known as SAHA (suberoylanilide hydroxamic acid), on the re-expression of ER $\alpha$ and PR receptors in TNBC cells. Vorinostat induced the re-expression of $\mathrm{ER} \alpha$ and $\mathrm{PR}$ receptors in TNBC cells with a basal-like 2 phenotype, as well as in HCC70 and HCC1806 (African American cell lines), when treated for $24 \mathrm{~h}$ (Figures $1 \mathrm{~A}$ and B). Treatment with the dietary agent, I3C, also caused the reexpression of ER $\alpha$ in HCC70 cells and PR in HCC1806 cells.

Figure 2 demonstrates the effect of treatment with vorinostat and I3C on two other subtypes: i) HCC1143 (basal-like 1) (Figure 2A), and ii) BT549 (M) (Figure 2B). Vorinostat increased the expression of PR in both HCC1143 and BT549 cells. Vorinostat also increased the expression of $\mathrm{ER} \alpha$ in BT549 cells but not in HCC1143 cells. The dietary agent, I3C, increased the expression of ER $\alpha$ significantly in both cell subtypes. I3C had no effect on PR expression in BT549 cells but it did increase PR in HCC1143 cells.

Immunostaining confirmed the re-expression of ERQ in HCC70 cells (Figure 3). The control cells showed no nuclear $\mathrm{ER} \alpha$ staining (Figure $3 \mathrm{~A}$ ) compared to the vorinostat-treated cells (Figure 3B), I3C-treated cells (Figure 3C), or the combination of vorinostat-IC3-treated cells (Figure 3D). 
Expression of ER $\alpha, P R$ and HER2 Receptors

in Triple Negative Breast Cell Lines

A

HCC70

ER $\alpha$
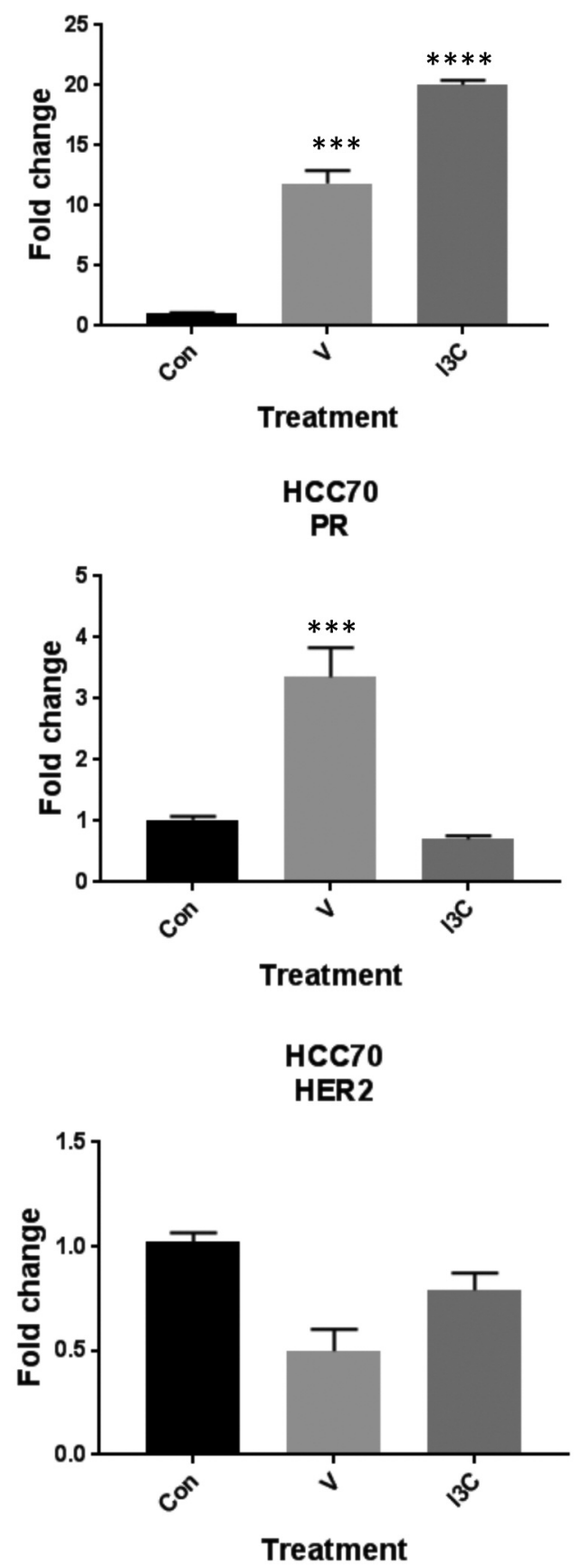

B

HCC 1806

ER $\alpha$

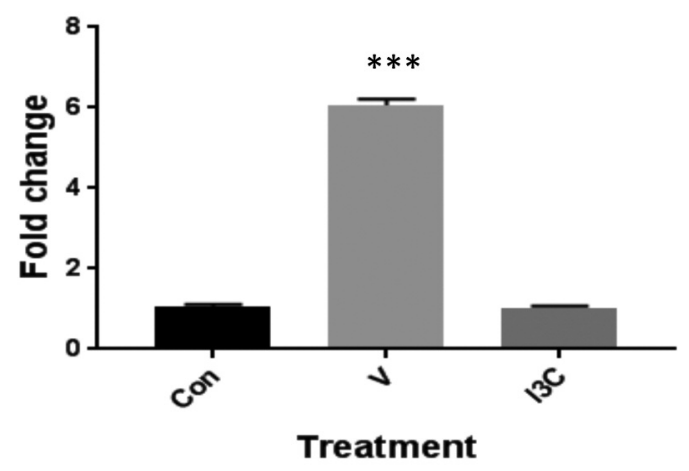

HCC 1806
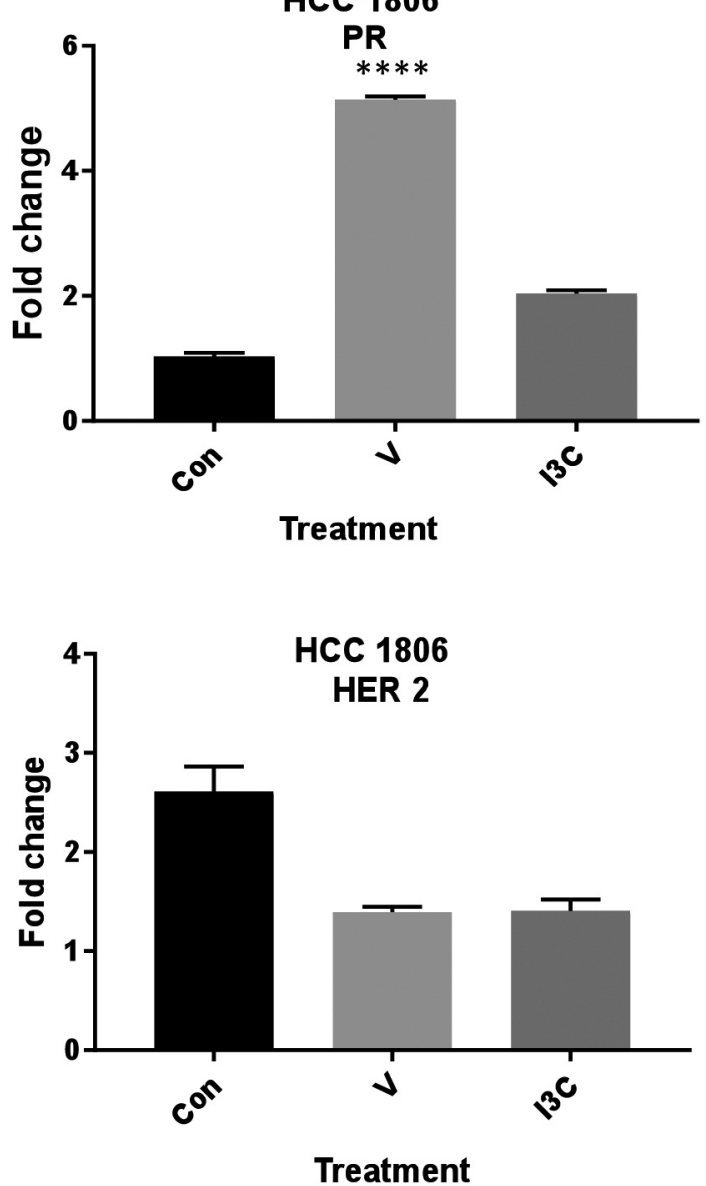

Figure 1. Real-time PCR analysis of ER, PR, and HER2 receptor expression in HCC70 and HCC1806 TNBC cells. Vorinostat re-expression of ER $\alpha$ and PR receptors in the two basal-like 2 cell subtypes, HCC70 (A) and HCC1806 (B) $(p \leq 0.001)$. Treatment with the dietary agent, I3C, also re-expressed ERa in HCC70 cells $(A)$ and PR in HCC1806 cells $(B)(p \leq 0.0001)$. All values represent the mean $\pm S D$ from three independent experiments. Con: Untreated control; V: vorinostat; I3C: indole-3-carbinol; ER $\alpha$ : estrogen receptor $\alpha$; PR: progesterone receptor; HER-2: human epidermal growth factor receptor-2. 


\section{Expression of ER $\alpha$ and PR Receptors in Triple Negative Breast Cell Lines}

A HCC1143 ER $\alpha$
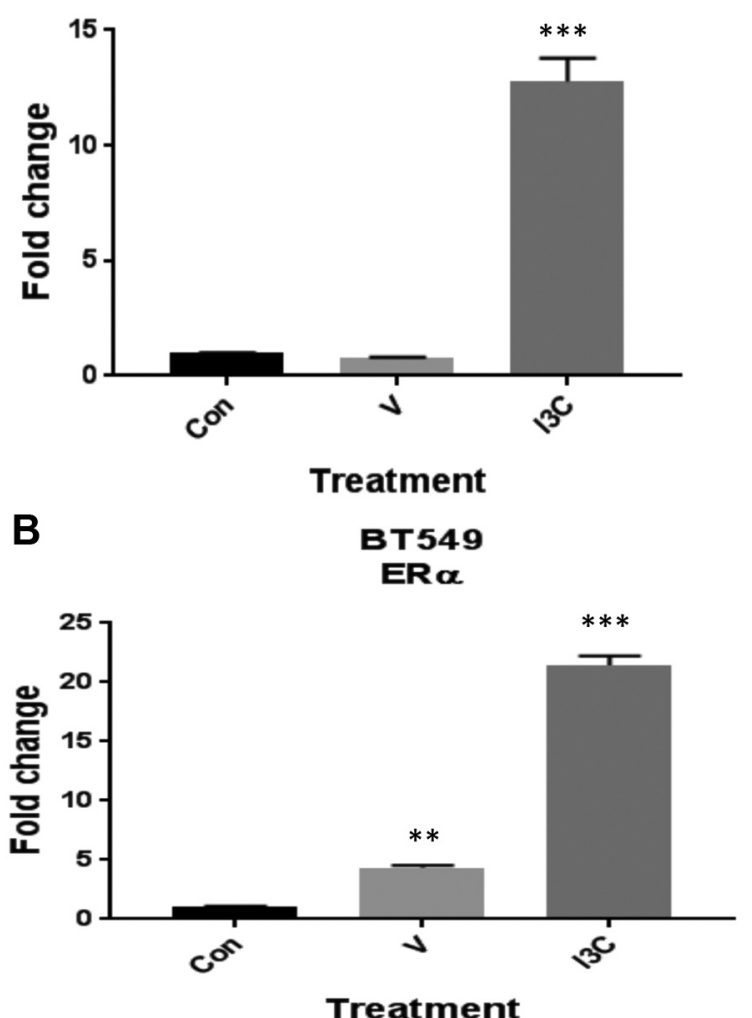

HCC1143

PR

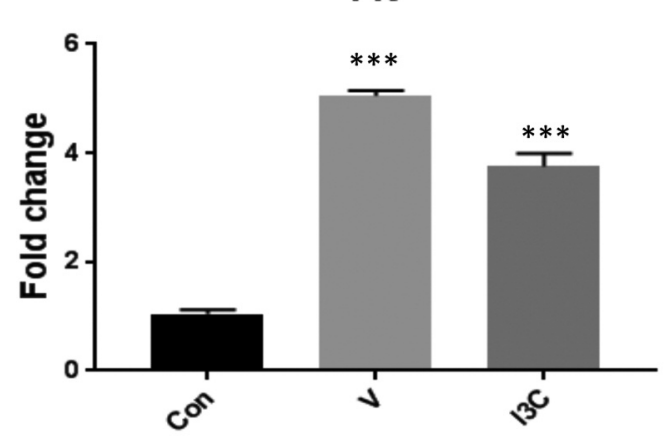

Treatment

BT549

PR

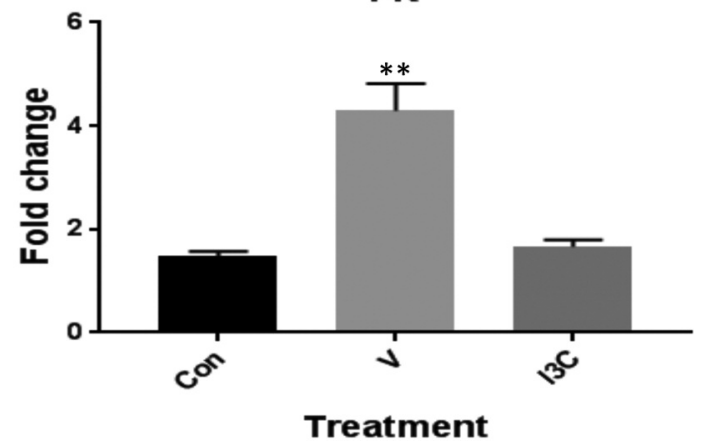

Figure 2. Gene expression profiles of ERQ and PR in HCC1143 and BT549 triple negative breast cancer cells. Vorinostat increased the expression of PR in both HCC1143 (A) and BT549 cells $(B)(p \leq 0.001)$. Vorinostat also increased the expression of ERa in BT549 cells $(p \leq 0.01)(B)$ but not in HCC1143 cells (A). The dietary agent, I3C, increased ERa expression in both subtypes of TNBC, HCC1143 (A) and BT549 (B) ( $p \leq 0.001) .13 C$ increased PR expression in HCC1143 cells $(p \leq 0.001)$ but had no effect in BT549 cells. All values represent the mean $\pm S D$ from three independent experiments. Con: Untreated control; V: vorinostat; I3C: indole-3-carbinol; ER $\alpha$ : estrogen receptor $\alpha$; PR: progesterone receptor.

Immunostaining confirmed the nuclear re-expression of ER $\alpha$ in HCC1806 TNBC cells (Figure 4).

Another subtype of TNBC, the MDA-MB231 cells, showed re-expression of the ER $\alpha$ after $6 \mathrm{~h}$ as both RNA (5fold, $p \leq 0.0001$ ) and protein (2-fold) (Figure 5A, left and right panel, respectively). The sensitivity to tamoxifen treatment was also tested in this subtype, where, in combination with vorinostat, cell growth was further inhibited $(p \leq 0.0001)$ and all other treatments significantly inhibited growth compared to the control (Figure 5B). Vorinostat's effect on this cell line occurred sooner compared to the other subtypes.

Sensitivity to Tamoxifen in Basal-2 subtypes of TNBC. The lack of effective treatment using targeted therapies is one of TNBC challenges. However, here, cells of the most aggressive TNBC BL2 subtype responded to tamoxifen when treated with vorinostat (Figure 6). Both of these subtypes, HCC70and HCC1806 are from two different African American women, as identified by their unique ATCC number. One exciting finding was that tamoxifen alone significantly inhibited the growth of these two basal-2 TNBC subtype cells. This was not noted in MB-231 cells, which is a different TNBC subtype, as shown in Figure 5B. Furthermore, vorinostat and $\mathrm{I} 3 \mathrm{C}$ alone and in combination decreased growth in these two TNBC cell lines.

Invasion assay. TNBC is not only aggressive but also highly invasive. Figure 7 shows a representative figure of the most aggressive type of the two basal-2 cell lines in our study, HCC70. The invasiveness of this line was inhibited by 


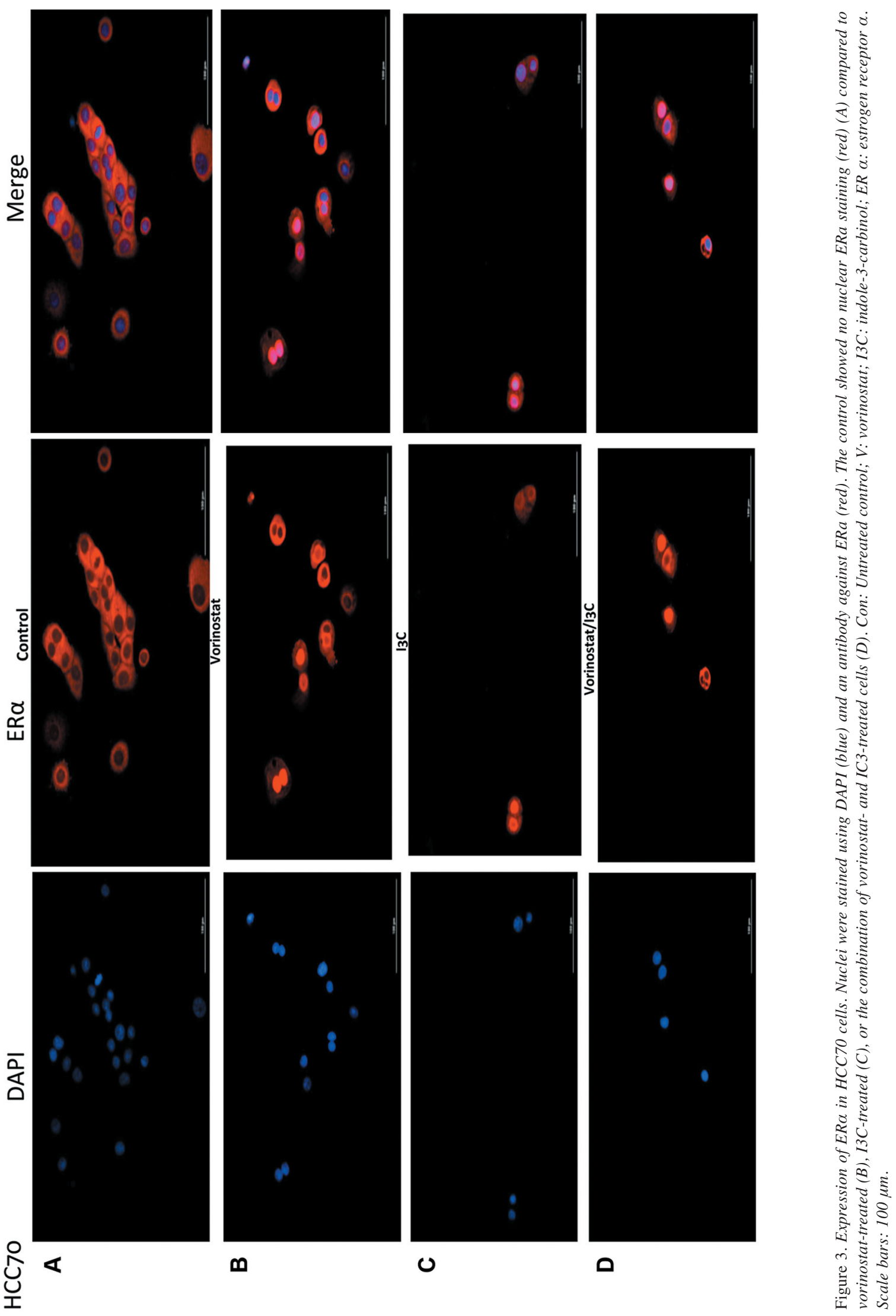



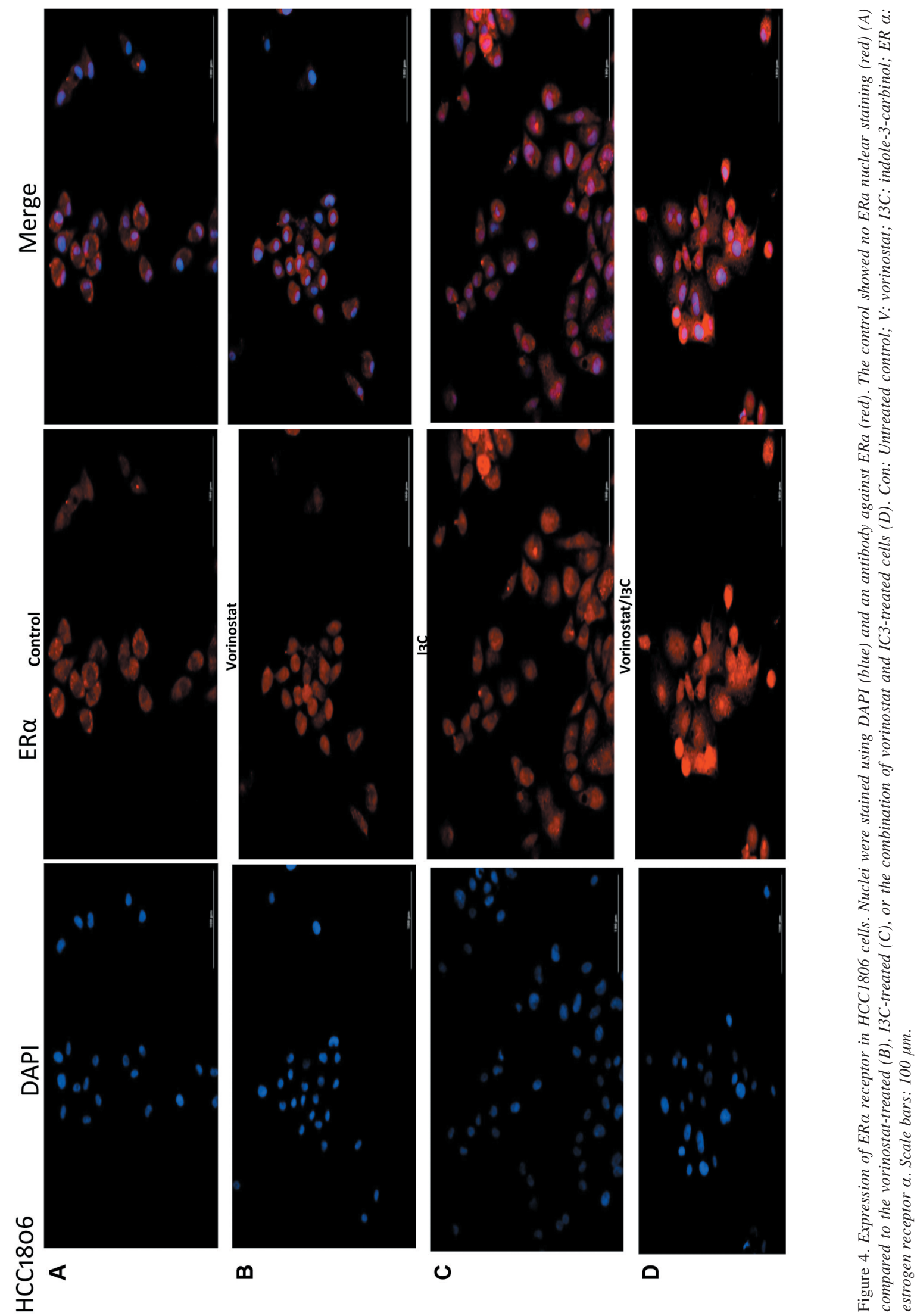


\section{Vorinostat effects on ER $\alpha$ Receptor Expression and Growth in MDA-MB-231 TNBC Cells}

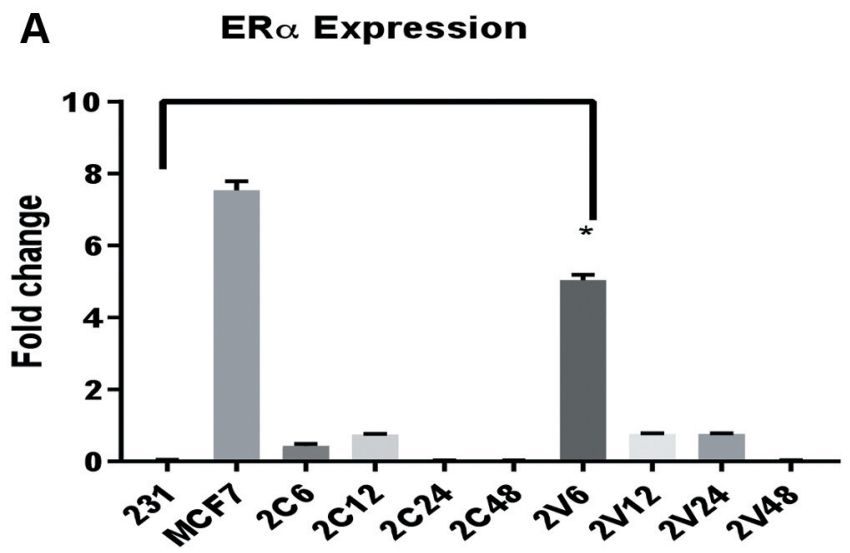

Western Blot Analysis of MDA-MB-231

Time Course
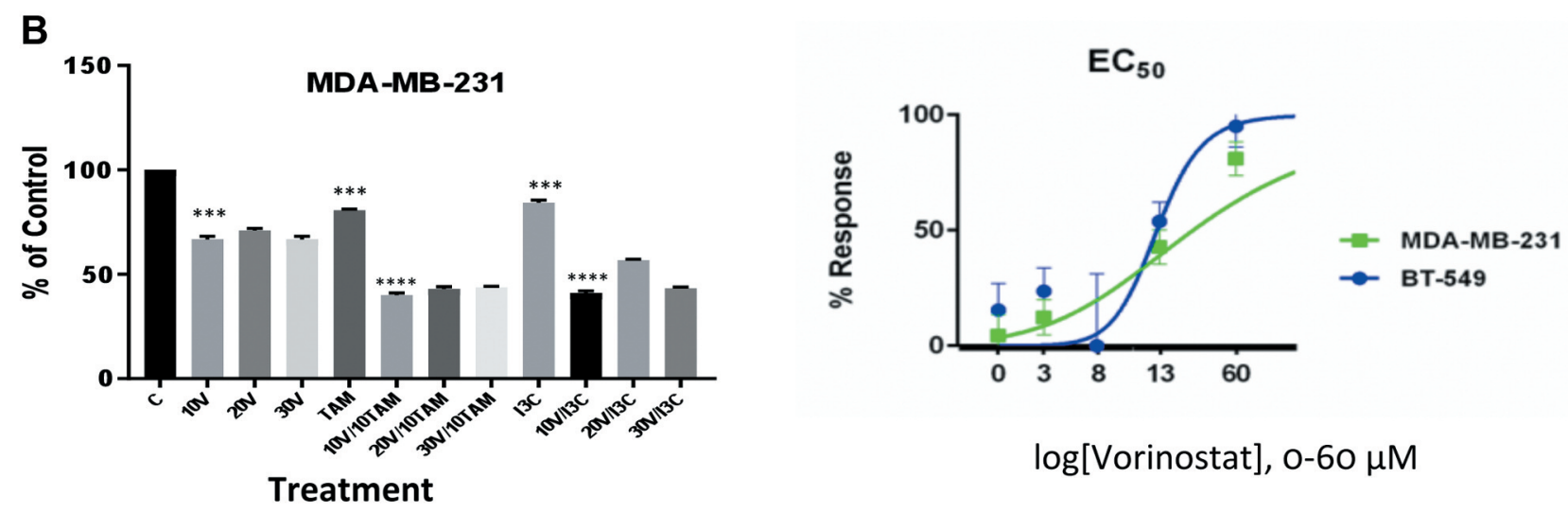

Figure 5. Effects of vorinostat on ERa receptor expression and cell growth. (A) Time course of the re-expression of ERQ in MB-231 TNBC cells untreated $(2 \mathrm{C})$ and those treated with vorinostat $(2 \mathrm{~V})(10 \mu \mathrm{M})$. Maximum ERa expression was noted at $6 \mathrm{~h}$ at both the RNA and protein levels $($ left and right panel, respectively). (B) MB-231 cells growth inhibition was noted with vorinostat, tamoxifen and indole-3-carbinol alone, $p \leq 0.001$ and greater inhibition was noted in combination with vorinostat at all concentrations $(p \leq 0.0001)$. All values represent the mean $\pm S D$ from three independent experiments. ${ }^{* *} p \leq 0.001, * * * * \leq 0.0001 . C$ : Control; V: vorinostat: TAM: tamoxifen; I3C: indole-3-carbinol; ER $\alpha:$ estrogen receptor $\alpha$.

vorinostat and I3C. Similar results were seen for all other cell lines. We also noted that treatment with progesterone significantly increased the invasiveness in this cell line; however, combined treatment with vorinostat and progesterone decreased the invasive capacity of HCC70 cells.

HDAC total activity. We observed inhibition of HDAC activity in two subtypes of triple negative breast cancer cell lines: i) in the mesenchymal BT549 tamoxifen treatment (Figure 8A, $p \leq 0.013$ ) and ii) the basal-like 2 HCC70 line (Figure $8 \mathrm{C}$ ). Results are also shown for MCF7 (Figure 8D) and MCF10A (Figure 8E), which is a non-malignant cell line. Vorinostat, as well as I3C and tamoxifen inhibited the overall HDAC activity more in the HCC70 cell line (Figure
$8 C$ ), even though these three treatments similarly affected HDAC activity in the MC7 cell line (Figure 8D), a non-triple negative cell line.

HDAC7 inhibition by vorinostat. Increased HDAC7 has been associated with increases in cancer stem cell proliferation (56), thus, the possibility that vorinostat and I3C may be acting as HDACis is highly significant since HDACs are considered to play a critical role in chemoresistance (57). To determine if vorinostat affected HDAC7 in the HCC70 cell line, we performed western blot and real-time PCR analysis. Our investigation revealed a significant decrease in HDAC7 at both RNA and protein levels. Specifically, western blots analysis in MDA-MB231 and HCC70 TNBC cells following treatment with 


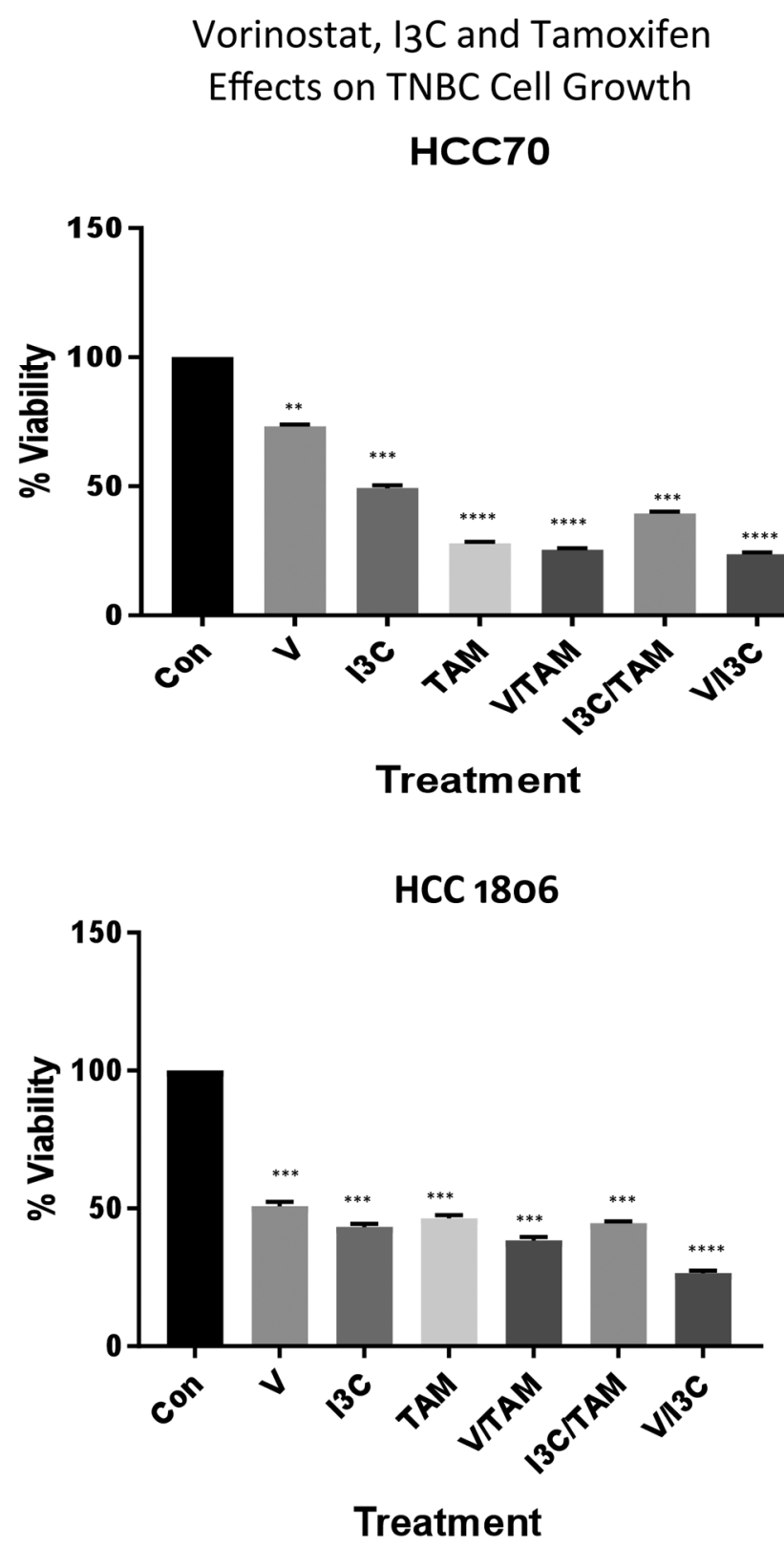

Figure 6. Effects of vorinostat, I3C and Tamoxifen on Cell Growth. Sensitivity to tamoxifen was noted in both TNBC cell lines, representing the Basal-2 subtype. Both HCC70 and HCC1806 decreased growth alone and further when treated with vorinostat. I3C and tamoxifen on their own significantly inhibited the growth of both Basal-2 cell lines. $* * p \leq 0.01, * * * p \leq 0.001, * * * * p \leq 0.0001$. C: Control; V: vorinostat: TAM: tamoxifen; I3C: indole-3-carbinol.

vorinostat showed that HDAC7 was significantly decreased in HCC70 compared to MDA-MB-231 cells (Figure 9A). Similarly, in Figure 9B real-time analysis showed decreased HDAC7 expression in HCC70 cells following treatment with vorinostat.
Effects of Vorinostat, $\mathrm{I}_{3} \mathrm{C}$ and Progesterone Alone or in Combination on Cell Invasion

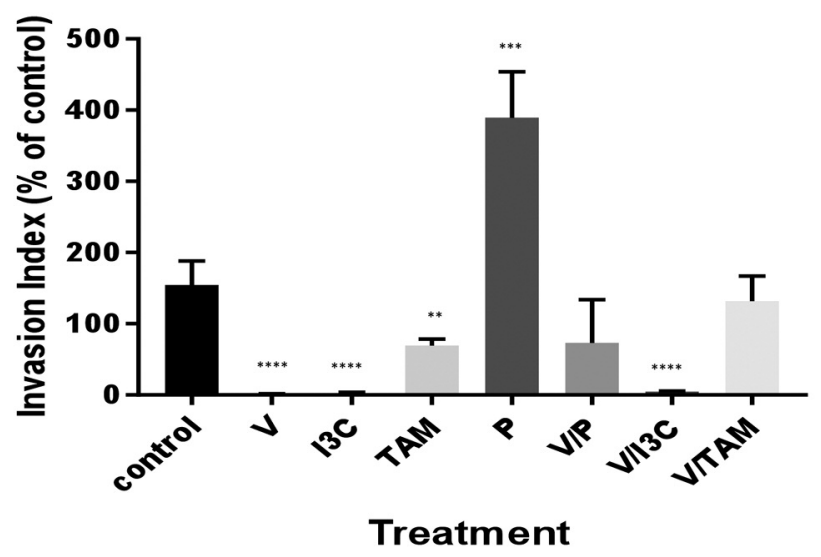

Figure 7. Effects of vorinostat, I3C and progesterone alone or in combination on cell invasion. Vorinostat (V) and I3C(indole-3-carbinol) significantly inhibited cell invasion of HCC7O cells alone and in combination in this in vitro invasion assay. However, tamoxifen alone inhibited invasion but not in combination with vorinostat. Treatment with progesterone $(P)$ significantly increased cell invasion. All values represent the mean $\pm S D$ from three independent experiments. **pValue $\leq 0.01, * * * p$-Value $\leq 0.001, * * * *$-Value $\leq 0.001$. C: Control; V: vorinostat; TAM: tamoxifen; I3C: indole-3-carbinol; P: progesterone.

\section{Discussion}

TNBC is an aggressive cancer that is molecularly characterized to an extent $(1,58)$. Here we demonstrated that the TNBC cell subtypes not only bear different molecular signatures but also show different responses to treatment. The lack of therapies for TNBC is an unmet medical need. This is particularly true for African Americans and Latin women who have higher rates of TNBC compared to other women (59). There is growing evidence that TNBC-related disparities may actually drive the aggressive biology of this type of cancer, observed in AfricanAmerican TNBC patients $(4,8)$. Other treatment barriers, such as screening, stage at diagnosis, income and biological factors have been identified as contributing factors to the disparities of TNBC in minority populations (6-13). In most cases, standard chemotherapy is usually the systemic treatment for advanced TNBC however, emerging treatments are currently being investigated, including epigenetic therapies. Epigenetic "signatures" have been shown in patients' molecular profiles with TNBC and the possibility of re-expressing specific genes through epigenetic drugs that could be then targeted for therapy could be very promising $(11,12)$. In addition to the reversal of epigenetic mechanisms by drugs, a number of studies have succeeded in modulating the expression of specific genes involved in cancer development through dietary agents $(60,61)$, some of which have shown anti-cancer effects in breast cancer 
HDAC Activity in Breast Cancer Cell Lines

A

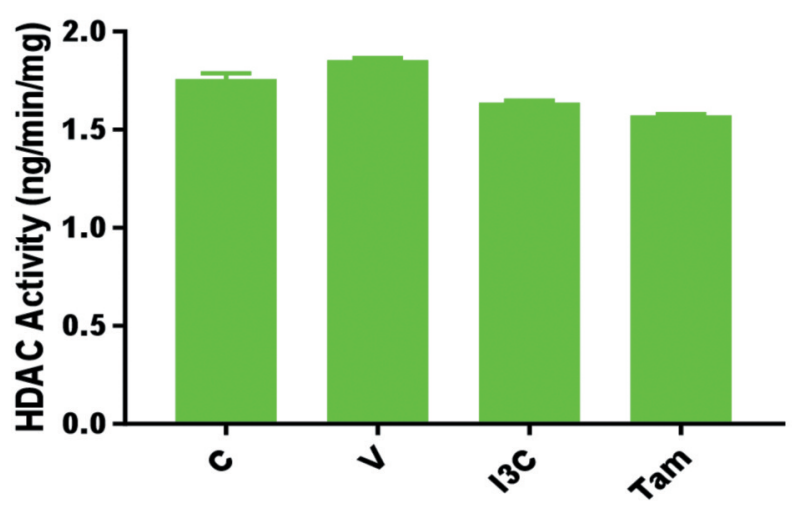

Treatment

C

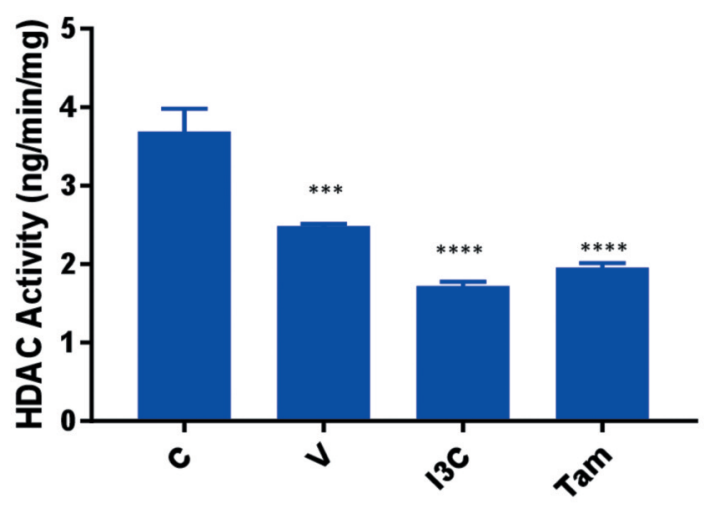

Treatment
B HCC1806

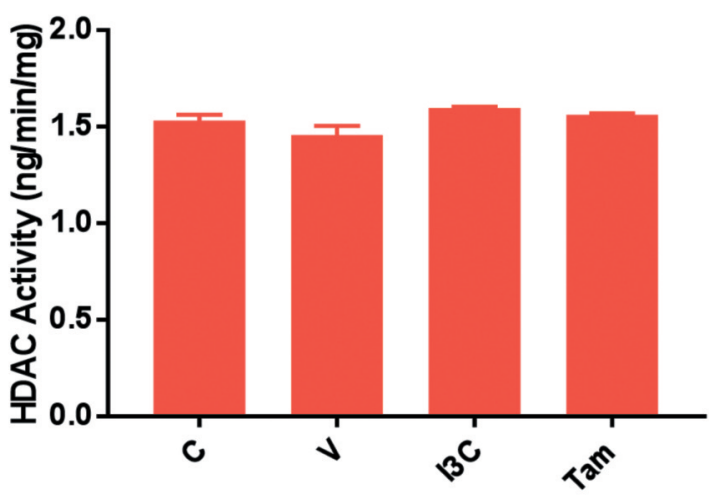

Treatment

D

MCF7

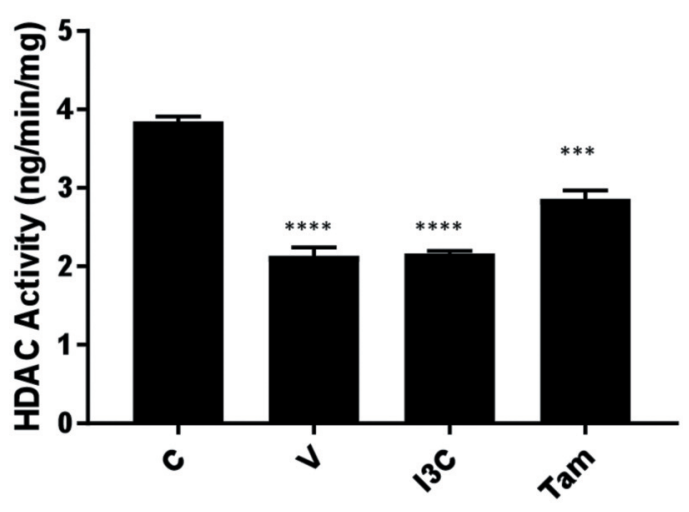

Treatment

E

MCF 10A

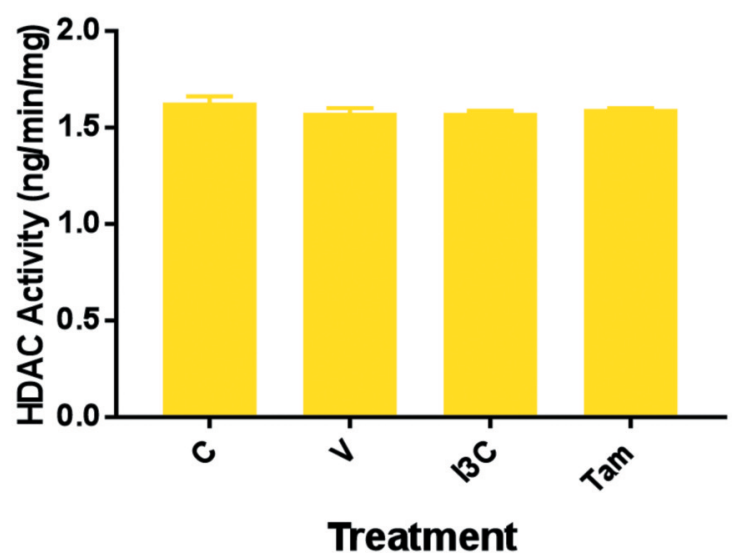

Figure 8. HDAC activity in breast cancer cell lines. Modest effects were noted on the global HDAC activity, except in HCC70 cells, where a significant decrease was noted following treatment with vorinostat, Tamoxifen and I3C. MCF7 cells also showed a significant decrease in activity with Vorinostat, I3C and Tamoxifen. All values represent the mean $\pm S D$ from three independent experiments. $* * * p \leq 0.001, * * * * p \leq 0.0001 . C$ : Control; $V$ : vorinostat; TAM: tamoxifen; I3C: indole-3-carbinol. 


\section{HDAC 7 Gene and Protein Expression in TNBC Cell Lines}

A

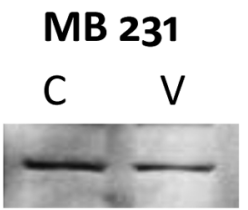

HDAC7
HCC70

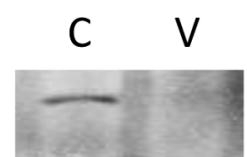

HDAC7

\section{Gene Expression}
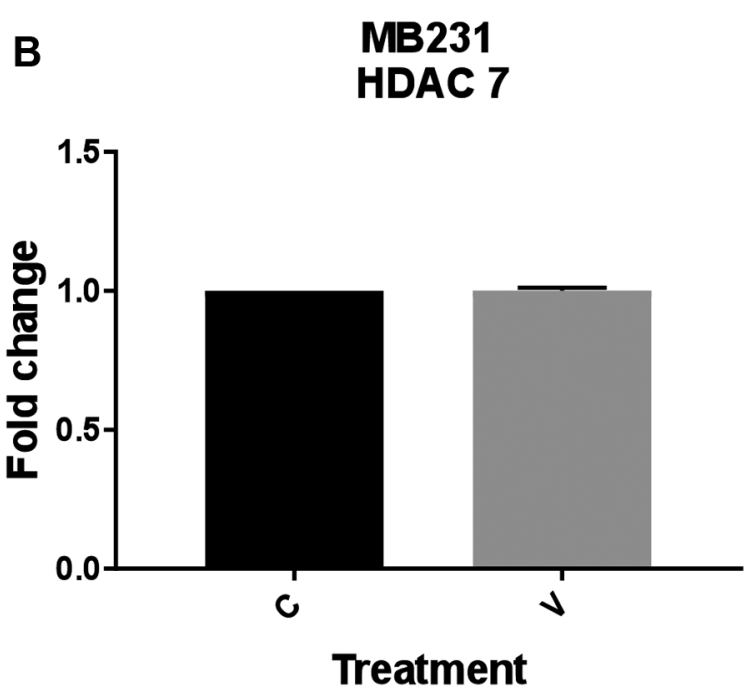

HCC70 HDAC 7

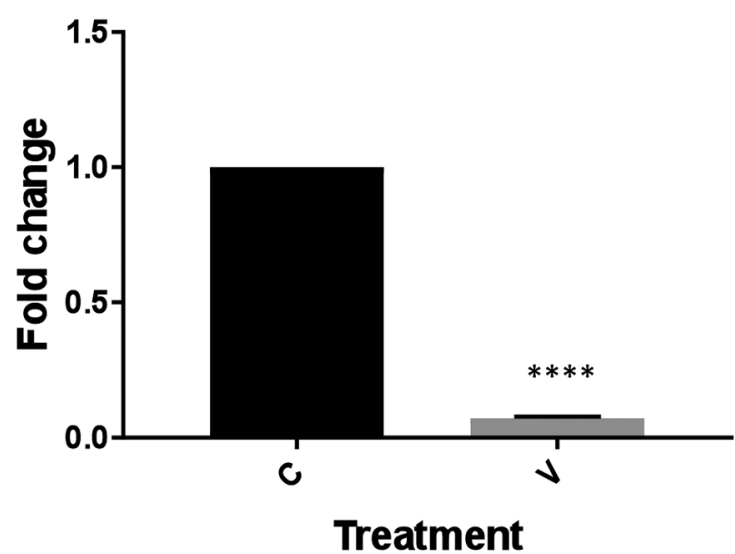

Figure 9. Western blots and real-time PCR of HDAC7 expression in MDA-MB-231 and HCC70 TNBC cells. HDAC7 protein was significantly decreased in HCC70 subtype when treated with vorinostat compared to the control or to MDA-MB-231 (A). (B) Shows decreased HDAC7 gene expression in HCC70 cells following treatment with vorinostat. All values represent the mean $\pm S D$ from three independent experiments. ****pValue $\leq 0.0001$. C: Control; V: vorinostat.

$(62,63)$. Such an example involves cruciferous vegetables containing $\mathrm{I} 3 \mathrm{C}$, and these are being investigated in clinical trials (64-66). I3C can affect TNBC through estrogen-independent actions, including blocking cell cycle progression and cell growth (67), increasing apoptosis (68) and inhibiting metastasis (69). Here, we showed that I3C enhanced the anti-cancer effects of vorinostat. In the basal-2 TNBC cell line, HCC70, IC3 significantly decreased their HDAC activity. Combining I3C and vorinostat had an effect on several cellular pathways, suggesting promising solutions for treating TNBC.

Our study demonstrated differences with regards to the reexpression of critical receptors in subtypes of TNBC cell lines, providing evidence for the importance of molecular profiling of individual cancers (or an individual's cancer), especially for this type of breast cancer. TNBC, particularly the aggressive genotypes, cannot be subjected to targeted therapies due to the absence of expression of specific receptors (ER, PR and Her2). The typical available treatments are surgery, chemotherapy, and/or radiation, while in recent years several new therapeutic options are used in TNBC (70). These options include treatment with poly-(ADP-ribose)-polymerase (PARP) inhibitors (71), angiogenesis inhibitors (72), rapamycin (mTOR) inhibitors (73), and androgen inhibitors (74), however, the efficacy of these drugs remains a problem. Clinical trials are investigating targeted therapies as single agents or in combination with other drugs (75), such as epigenetic drugs (76). Some of these drugs have already been approved by FDA for lymphoma, multiple myeloma and colon cancer $(77,78)$.

Among the targeted therapies investigated in TNBC, HDACis appear very promising $(31,38)$. HDACis exert their effect through many mechanisms, such as by inhibition of proliferation and angiogenesis, as well as enhancement of Tcell-mediated tumor immunity $(39-41,79)$. Some studies have shown these agents' ability to inhibit the capacity of cancer stem cells for self-renewal, leading to a decrease in the relapse of tumors' aggressive behavior $(32,33)$. 
TNBC lacks the expression of the critical receptors ER, PR and HER2, which are targets for therapies in other types of breast cancer. Our study demonstrated the ability of vorinostat to re-express some of these critical receptors in different subtypes of TNBC. Aggressive subtypes of TNBC were able to re-express ER $\alpha$ and PR, which sensitized cells to the antiestrogen drug, tamoxifen. Only certain subtypes of TNBC responded to vorinostat when receptors were re-expressed. Our study confirms other studies (80) in which vorinostat reexpressed ER $\alpha$ in some but not all TNBC cell lines. Our study clearly demonstrated that different cell subtypes bear distinct molecular signatures that play a critical role in drug response. Precision medicine is extremely important, and molecular profiling of patients' tumors may prove to be one of the most effective ways for handling aggressive cancers, such as TNBC. One exciting finding here was the fact that tamoxifen alone significantly inhibited the growth of a certain cell subtype, particularly of the two African American lines of the basal 2 subtype. Recent findings have demonstrated the presence of ER $\beta$ in subtypes of TNBC (81), while this receptor has been found in a number of African American TNBCs $(82,83)$. By analogy, this could suggest that tamoxifen may be useful in such TNBCs expressing ER $\beta$.

TNBC is not only an aggressive cancer, but a highly resistant one to most current therapies. Studies have shown that expression of HDAC7 is associated with cancer stem cell progression and a resistant phenotype (84). Vorinostat significantly inhibited HDAC7 expression at both RNA and protein levels. HDAC inhibitors, such as vorinostat, are currently in clinical trials on their own or in combination for a number of other cancers (78) and are proving very promising with only few side effects.

In conclusion, the HDAC inhibitor, vorinostat, has shown specificity for different subtypes of TNBC, which could potentially be used as an efficient treatment in patients. Although this manuscript focused largely on vorinostat, the use of the dietary component, $\mathrm{I} 3 \mathrm{C}$, showed that it has the ability to enhance the vorinostat anticancer effects in certain TNBC subtypes. More research is needed to further investigate the mechanism through this new emerging agent and its ability to tackle an aggressive cancer, such as TNBC.

\section{Funding}

This study was funded to Beverly Lyn-Cook through a grant from the FDA-Office of Women's Health.

\section{References}

1 Hudis CA and Gianni L: Triple-negative breast cancer: An unmet medical need. Oncologist 16(1): 1-11, 2011. PMID: 21278435. DOI: 10.1634/theoncologist.2011-S1-01

2 Bauer KR, Brown M, Cress RD, Parise CA and Caggiano V: Descriptive analysis of estrogen receptor (ER)-negative, progesterone receptor (PR)-negative, and HER-2-negative invasive breast cancer: a population-based study from the California cancer Registry. Cancer 109(9): 1721-1728, 2007. PMID: 17387718. DOI: $10.1002 / \mathrm{cncr} .22618$

3 Carey LA, Perou CM, Livasy CA, Dressler LG, Cowan D, Conway K, Karaca G, Troester MA, Tse CK, SEdmiston S, Deming SL, Geradts J, Cheang MCU, Nielsen TO, Moorman PG, Earp HS, Robert C and Millikan RC: Race, breast cancer subtypes, and survival in the Carolina Breast Cancer Study. JAMA 295(21): 2492-2502, 2006. PMID: 16757721. DOI: 10.1001/jama.295.21.2492

4 Wend P, Runke S, Wend K, Anchondo B, Yesayan M, Jardon M, Hardie N, Loddenkemper C, Ulasov I, Lesniak MS, Wolsky R, Bentolila LA, Grant SG, Elashoff D, Lehr S, Latimer JJ, Bose S, Sattar H, Krum SA and Miranda-Carboni GA: WNT10/ $\beta$ catenin signaling induces HMGA2 and proliferation in metastic triple-negative breast cancer. EMBO Mol Med 5(2): 264-279, 2013. PMID: 23307470. DOI: 10.1002/emmm.201201320

5 Sharma P, Klemp JR, Kimler BF, Mahnken JD, Geier LJ, Khan QJ, Elia M, Connor CS, McGinness MK, Mammen JM, Wagner JL, Ward C, Ranallo L, Knight CJ, Stecklein SR, Jensen RA, Fabian CJ and Godwin AK: Germline BRCA mutation evaluation in a prospective triple-negative breast cancer registry: implications for hereditary breast and/or ovarian cancer syndrome testing. Breast Cancer Res Treat 145(3): 707-714, 2014. PMID: 24807107. DOI: 10.1007/s10549-014-2980-0

6 Sturtz LA, Melley J, Mamula K, Shriver CD and Ellsworth RE: Outcome disparities in African American women with triple negative breast cancer: a comparison of epidemiological and molecular factors between African American and Caucasian women with triple negative breast cancer. BMC Cancer 14: 62, 2014. PMID: 24495414. DOI: 10.1186/1471-2407-14-62

7 Lindner R, Sullivan C, Offor O, Lezon-Geyda K, Halligan K, Fischbach N, Shah M, Bossuyt V, Schulz V, Tuck DP and Harris LN: Molecular phenotypes in triple negative breast cancer from African American patients suggest targets for therapy. PLoS One 188(11): e71915, 2013. PMID: 24260093. DOI: 10.1371/journal.pone.0071915

$8 \mathrm{Wu}$ Y, Sarkissyan M, Elshimali Y and Vadgama JV: Triple negative breast tumors in African-American and Hispanic/Latina women are high in CD44+, low in CD24+, and have loss of PTEN. PLoS One 8(10): e78259, 2013. PMID: 24167614. DOI: 10.1371/journal.pone.0078259

9. Dolle JM, Daling JR, White E, Brinton LA, Doody DR, Porter PL and Malone KE: Risk factors for triple negative breast cancer in women under 45. Cancer Epidemiol Biomarkers Prev 18(4): 1157-1166, 2009. PMID: 19336554. DOI: 10.1158/10559965.EPI-08-1005

10 Whitesell M, Al-Najar S, Bowser G and Brown MA: Cultural and environmental factors of triple negative carcinomas. Cancer Res J 2(2): 18-28, 2014. DOI: 10.11648/j.crj.20140202.12

11 Yao S and Ambrosone CB: Associations between vitamin D deficiency and risk of aggressive breast cancer in AfricanAmerican women. J Steroid Biochem Mol Biol 136: 337-341, 2013. PMID: 22995734. DOI: 10.1016/j.jsbmb.2012.09.010

12 Go Y, Chung M and Park Y: Dietary patterns for women with triple negative breast cancer and dense breast. Nutri Cancer 68(8): 1281-1288, 2016. PMID: 27682242. DOI: $10.1080 / 01635581.2016 .1225102$ 
13 Lee E, Levine EA, Franco VI, Allen GO, Gong F, Zhang Y and $\mathrm{Hu} J \mathrm{~J}$ : Combined genetic and nutritional risk models of triple negative breast cancer. Nutri Cancer 66(6): 955-963, 2014. PMID: 25023197. DOI: 10.1080/01635581.2014.932397

14 Zhao M, Howard EW, Parris AB, Guo AZ, Zhao Q and Yang X: Alcohol promotes migration and invasion of triple-negative breast cancer cells through activation of p38 MAPK and JNK. Mol Carcinog 56(3): 849-862, 2017. PMID: 27533114. DOI: $10.1002 / \mathrm{mc} .22538$

15 Williams LA, Olshan AF, Hong C-C, Bandera AEV, Rosenberg L, Cheng T-YD, Lunetta KL, McCann SE, Poole C, Kolonel LN, Palmer JR, Ambrosone CB and Troester MA: Alcohol intake and breast cancer risk in African American women from the AMBER Consortium. Alcohol intake and breast cancer risk in African American women from the AMBER Consortium. Cancer Epidemiol Biomarkers Prev 26(5): 787-794, 2017. PMID: 28420652. DOI: 10.1158/1055-9965.EPI-16-0792

16 Prabbakar D, Harris L and Thompson CL: Effect of current smoking on triple negative breast cancer. J Clin Oncol 33(15): Suppl 1592-1592, 2015. DOI: 10.1200/jco.2015.33.15_suppl. 1592

17 Goldvaser H, Gal O, Rizel S, Hendler TD, Neiman V, Shochat T, Sulkes A, Brenner B and,Yerushalmi R: The association between smoking and breast cancer characteristics and outcome. BMC Cancer 17: 624, 2017. PMID: 28874120. DOI: 10.1186/s12885-017-3611-z

18 John EM, Hines LM, Phipps Al, Koo J, Teri A Longacre TA, Ingles SA, Baumgartner $\mathrm{KB}$, Slattery $\mathrm{ML}$ and $\mathrm{Wu} \mathrm{AH}$ : Reproductive history, breast-feeding and risk of triple negative breast cancer: The Breast Cancer Etiology in Minorities (BEM) study. Int J Cancer 142(11): 2273-2285, 2018. PMID: 29330856. DOI: $10.1002 / \mathrm{ijc} .31258$

19 Islami, F, Liu Y, Jemal, A, Zhou J, Weiderpass E, Colditz G, Boffetta $\mathrm{P}$ and Weiss M: Breastfeeding and breast cancer risk by receptor status - a systematic review and meta-analysis. Ann Oncol 26: 2398-2407, 2015. PMID: 26504151. DOI: 10.1093/annonc/ $\operatorname{mdv} 379$

20 Sun H, Zou J, Chen L, Zu X, Wen G and Zhong J: Triple-negative breast cancer and its association with obesity. Mol Clin Oncol 7(6): 935-942, 2017. PMID: 29285353. DOI: 10.3892/mco.2017.1429

21 Chen H, Wu J, Zhang Z, Tang Y, Li X, Liu S, Cao S and Li X: Association between BRCA status and triple-negative breast cancer: A meta-analysis. Front Pharmacol 9: 909, 2018. PMID: 30186165. DOI: 10.3389/fphar.2018.00909018

22 Peshkin BN, Alabex ML and Isaacs C: BRAC1/2 mutations and triple negative breast cancers. Breast Dis 32(1-2): 25-33, 2010. PMID: 21778580. DOI: 10.3233/BD-2010-0306

23 Engel C, Rhiem K, Hahsen E, Loibl S, Weber KE, Seilelr S, Zachariae S, Hauke J, Wappenschmidt B, Waha A, Blumcke B, Kiechie M, Meindi A, Niederacher D, Bartram CR, Speiser D, Schlegelberger B, Arnold N, Wieacker P, Leinert E, Gehrig A, Briest S, Kast K, Riess O, Emons G, Weber BHF, Engel J, Schmutzler RK, and the German Consortium for Hereditary Breast and Ovarian Cancer (GC-HBOC): Prevalence of pathogenic BRCA1/2 germline mutations among 802 women with unilateral triple-negative breast cancer without family cancer history. BMC Cancer 18: 265, 2018. DOI: 10.1186/s12885-018-4029-y

24 Evans DG, Howel A, Ward D, Lalloo F, Jones JL and Eccles DM: Prevalence of BRCA1 and BRCA2 mutations in triple negative breast cancer. J Med Genet 48: 520-522, 2011. PMID: 25682074. DOI: $10.1007 / \mathrm{s} 10549-015-3293-7$

25 Shrmelish H, LaDuca H, Hu C, Steven T, Hart N, Na J, Thomas A, Akinhanmi M, Moore RM, Brauch H, Cox A, Eccles DM, Ewart-Toland A, Fasching PA, Fostira F, Garber J, Godwin AK, Konstantopoulou I, Nevanlinna H, Sharma P, Yannoukakos D, Yao S, Feng B-J, Davis BT, Lilyquist J, Pesaran T, Goldgar DE, Polley EC, Dolinsky JS and Couch FJ: Triple-negative breast cancer risk genes identified by multigene hereditary cancer panel testing. J Natl Cancer Inst 110(8): 855-862, 2018. PMID: 30099541. DOI: $10.1093 /$ jnci/djy 106

26 Romagnolo D, Daniels KD, Grunwald J, Ramos SA, Propper CR and Selmin OI: Epigenetics of breast cancer: modifying role of environmental and bioactive food compounds. Mol Nutr Food Res 6O(6): 1310-1329, 2016. PMID: 27144894. DOI: $10.1002 / \mathrm{mnfr} .201501063$

27 Rodríguez-Balada M, Roig B, Melé M, Salvat M, Martorell L, Borràs $\mathrm{J}$ and Gumà $\mathrm{J}$ : Germline promoter hypermethylation in BRCA1 and BRCA2 genes is not present in hereditary breast cancer patients. Clin Transl Oncol 20(9): 1226-1231, 2018. PMID: 29404838. DOI: 10.1007/s12094-018-1837-0

28 Temian DC, Ancuta L, Pop LA, Irimie AI and Berindan-Neagoe I: The epigenetics of triple-negative and basal-like breast cancer: Current knowledge. J Breast Cancer 21(3): 233-243, 2018. PMID: 30275851. DOI: 10.4048/jbc.2018.21.e41

29 Shao F, Sun H and Deng C-X: Potential therapeutic targets of triple-negative breast cancer based on its intrinsic subtype. Oncotarget 8(42): 73329-73344, 2017. PMID: 29069872. DOI: 10.18632/oncotarget.20274

30 Saha P and Nanda R: Concepts and targets in triple-negative breast cancer: recent results and clinical implications. Ther Adv Med Oncol 8(5): 351-359, 2019. PMID: 27583027. DOI: $10.1177 / 1758834016657071$

31 Yang X-J and Seto E: HATs and HDACs: from structure, function and regulation to novel strategies for therapy and prevention. Oncogene 26: 5310-5318, 2007. PMID: 17694074. DOI: $10.1038 /$ sj.onc.1210599

32 Lin P-C, Hsieh H-Y, Chu P-C and Chen CS: Therapeutic opportunities of targeting histone deacetylase isoforms to eradicate cancer stem cells. Int J Mol Sci 19(7): 1939, 2018. PMID: 30004423. DOI: 10.3390/ijms19071939

33 Borah A, Raveendran S, Rochani A, Maekawa T and Kumar DS: Targeting self-renewal pathways in cancer stem cells: clinical implications for cancer therapy. Oncogenesis 4: e177, 2015. DOI: $10.1038 /$ oncsis.2015.35

34 Serrano-Gomez SJ, Maziveyi M and Alahari SK: Regulation of epithelial-mesenchymal transition through epigenetic and posttranslational modifications. Mol Cancer 15: 18, 2016. PMID: 26905733. DOI: 10.1186/s12943-016-0502 x

35 Ropero S and Esteller M: The role of histone deacetylases (HDACs) in human cancer. Mol Oncol 1(1): 19-25, 2007. PMID: 19383284. DOI: 10.1016/j.molonc.2007.01.001

36 Li PT, Tsai YI and Chen CT: Increased histone deacetylase activity involved in the suppressed invasion of cancer cells survived from ALA-mediated photodynamic treatment. Int J Mol Sci 16(10): 23994-24010, 2015. PMID: 26473836. DOI: 10.3390/ijms161023994

37 Cang S, Feng J, Kunno S, Han L, Liu K, Sharma SC, Choudhury $\mathrm{M}$ and Chiao JW: Deficient histone acetylation and excessive deacetylase activity as epigenomic marks of prostate cancer 
cells. Int J Oncol 35: 1417-1422, 2009. PMID: 19885564. DOI: 10.3892/ijo_00000459

38 Fedele P, Orlando L and Cinieri S: Targeting triple negative breast cancer with histone deacetylase inhibitors. Expert Opin Investig Drugs 26: 1199-1206, 2017. PMID: 28952409. DOI: 10.1080/13543784.2017.1386172

39 Karamboulas C, Swedani A, Ward C, Al-Madhoun AS, Wilton S, Boisvenue S, Ridgeway AG and Skerjanc IS: HDAC activity regulates entry of mesoderm cells into the cardiac muscle lineage. J Cell Science 119: 4305-4314, 2006. PMID: 17038545. DOI: $10.1242 /$ jcs.03185

40 Koeneke E, Witt O and Oeheme I: HDAC family members intertwined in the regulation of autophagy: A druggable vulnerability in aggressive tumor entities. Cells 4: 135-168, 2015. PMID: 25915736. DOI: 10.3390/cells4020135

41 Huang JP and Ling K: EZH2 and histone deacetylase inhibitors induce apoptosis in triple negative breast cancer cells by differentially increasing H3 Lys27 acetylation in the BIM gene promoter and enhancers. Oncol Lett 14: 5735-5742, 2017. PMID: 29113202. DOI: 10.3892/ol.2017.6912

42 Park SY, Jun JA, Jeung KJ, Heo HJ, Sohn JS, Lee HY, Park CG and Kang J: Histone deacetylases 1, 6 and 8 are critical for invasion in breast cancer. Oncol Rep 25: 1677-1681, 2011. PMID: 21455583. DOI: 10.3892/or.2011.1236

43 Roos WP and Krumm A: The multifaceted influence of histone deacetylases on DNA damage signalling and DNA repair. Nucleic Acids Res 44(21): 10017-10030, 2016. PMID: 27738139. DOI: $10.1093 /$ nar/gkw922

44 Salgado E, Bian X, Feng A, Shim $H$ and Liang Z: Overexpression of HDAC9 promotes invasion and angiogenesis of triple negative breast cancer by regulating microRNA-206. Biochem Biophys Res Commun 503(2): 1087-1091, 2018. PMID: 29936177. DOI: 10.1016/j.bbrc.2018.06.120

45 Zhang $\mathrm{J}$ and Zhong Q: Histone deacetylase inhibitors and cell death. Cell Mol Life Sci 71(20): 3885-3901, 2014. PMID: 24898083 DOI: $10.1007 / \mathrm{s} 00018-014-1656-6$

46 Witt AE, Lee CW and Lee TI: Identification of a cancer stem cell-specific function for the histone deacetylases, HDAC 1 and HDAC7, in breast and ovarian cancer. Oncogene 36(12): 1701-1720, 2017. PMID: 27694895. DOI: 10.1038/onc.2016. 337

47 Guo XE, Ngo B, Modrek AS and Lee W-H: Identification of a cancer stem cell-specific function for the histone deacetylases, HDAC1 and HDAC7, in breast and ovarian cancer. Curr Drug Targets 15(1): 2-16, 2014. PMID: 24387338. DOI: 10.2174/ 1389450114666140106095151

48 Fan J, Yin WJ, Lu J-S, Wang L, Wu J, Wu F-Y, Di G-H, Shen $\mathrm{Z}-\mathrm{Z}$ and Shao Z-M: ER $\alpha$ negative breast cancer cells restore response to endocrine therapy by combination treatment with both HDAC inhibitor and DNMT inhibitor. J Cancer Res Clin Oncol 134(8): 883-890, 2008. PMID: 18264725. DOI: 10.1007/s00432-008-0354-x

49 Zhou L, Zhou W, Zhang H, Hu Y, Yu L, Zhang Y and Xia W: Progesterone suppresses triple-negative breast cancer growth and metastasis to the brain via membrane progesterone receptor $\alpha$. Int J Mol Med 40: 755-761, 2017. PMID: 28713912. DOI: $10.3892 /$ ijmm. 2017.3060

50 Scarpin KM, Graham JD, Mote PA and Clarke CL: Progesterone action in human tissues: regulation by progesterone receptor (PR) isoform expression, nuclear positioning and coregulator expression. Nucl Recept Signal, 2009. PMID: 200874307. DOI: 10.1621/nrs.07009

51 Daniel AR, Hagan CR and Lange CA: Progesterone receptor action: defining a role in breast cancer. Expert Rev Endocrinol Metab 6(3): 359-369, 2011. PMID: 21857868. DOI: 10.1586/eem.11.25

52 Zhou L. Zhou W, Zhang H, Hu Y, Yu, L Zhang Y, Zhang Y, Wang $\mathrm{P}$ and $\mathrm{Xia}$ W: Progesterone suppresses triple negative breast cancer growth and metastasis to the brain via membrane progesterone $\alpha$. Int J Mol Biol 40: 755-761, 2017. PMID: 28713912. DOI: $10.3892 / \mathrm{ijmm} .2017 .3060$

53 Hessel H, Poignée-Heger M, Lohmann S, Hirscher B, Andrea Herold A, Assmann G, Budczies J, Sotlar K and Kirchner T: Subtyping of triple negative breast carcinoma on the basis of RTK expression. J Cancer 9(15): 2589-2602, 2018. DOI: $10.7150 /$ jca. 23023

54 Nikolai BC, Lanz RB, York B, Dasgupta S, Mitsiades N, Creighton CJ, Tsimelzon A, Hilsenbeck SG, Lonard DM, Smith CL and O'Malley BW: HER2 signaling drives DNA anabolism and proliferation and E2F1-regulated genes. Cancer Res 76(6): 1463-1475, 2016. PMID: 26833126. DOI: 10.1158/00085472.CAN-15-2383

55 Pinto AC, Ades F, Azambuja ED and Piccart-Gebhart M: Trastuzmab for patients with HER2 positive breast cancer: delivery, duration and combination therapies. Breast 22(S2): S152S155, 2013. PMID: 24074778. DOI: 10.1016/j.breast.2013.07.029

56 Caslini C, Hong S, Yuguang, Ban J, Chen XS and Ince TA: HDAC7 regulates histone 3 lysine 27 acetylation and transcriptional activity at super-enhancer-associated genes in breast cancer stem cells. Oncogene 38: 6599-6614, 2019. PMID: 31375747. DOI: 10.1038/s41388-019-0897-0

57 Roca MS, Gennaro ED, and Budillon A: Implication for cancer stem cells in solid cancer chemo-resistance: Promising therapeutic strategies based on the use of HDAC inhibitors. J Clin Med 8(7): 912, 2019. PMID: 31247937. DOI: 10.3390/jcm8070912

58 Lehmann BD, Bauer JA, Chen X, Sanders MF, Chakravarthy $A B$, Shyr Y and Pietenpol JA: Identification of human triplenegative breast cancer subtypes and preclinical models for selection of targeted therapies. J Clin Invest 121(7): 2750-2767, 2011. PMID: 21633166. DOI: $10.1172 /$ JCI45014

$59 \mathrm{Wu}$ Y, Sarkissyan M, Elshimali Y and Vadgama JV: Triple negative breast tumors in African-American and Hispanic/Latina women are high in $\mathrm{CD} 44+$, low in $\mathrm{CD} 24+$, and loss of PTEN. PLOS 8(10): e78259, 2013 PMID: 24167614. DOI: 10.1371/journal.pone.0078259

60 Carlos-Reyes A, Lopez-Gonzalez JS, Meneses-Flores M, Gallardo-Rincon D, Ruiz-Garcia E, Marchat LA, Vega HA, de Va Cruz ONH and Lopez-Camarillo C: Dietary compounds as epigenetic modulating agents in cancer. Front Genet 10: 79, 2019. DOI: $10.3389 /$ fgene2019.00079

61 Montgomery M and Srinivassan A: Epigenetic regulation by dietary compounds in cancer prevention. Adv Nutr 10(6): 10121028, 2019. PMID: 31100104. DOI: 10.1093/advances/nmz046

62 Bradlow HL: Indole-3-carbinol as a chemoprotective agent in breast and prostate cancer. In Vivo 22(4): 441-445, 2008. PMID: 1872169.

63 Kapinova D A, Kubatka P, Golubnitschaja O, Kello M, Zubor P, Solar P and Pec M: Dietary phytochemicals in breast cancer research: anticancer effects and potential utility for effective chemoprevention. Environ Health Prev Med 23: 36, 2018, PMID: 30092754. DOI: 10.1186/s12199-018-0724-1 
64 Wang J and Jiang Y-F: Natural compounds as anticancer agents: Experimental evidence. World J Exp Med 2(3): 45-57, 2012. PMID: 24520533. DOI: 10.5493/wjem.v2.i3.45

65 Reed G, Peterson KS, Gray JC and Smith HJ: Phase I study of indole-3-carbinol in women: Tolerability and effects. Cancer Epidemiol Biomarkers Prev 14(8): 1953-1960, 2005. PMID: 16103443. DOI: 10.1158/1055-9965.EPI-05-0121

66 Brignall MS: Prevention and treatment of cancer with indole-3carbinol. Altern Med Rev 6(6): 580-589, 2001. PMID: 11804548.

67 Santi MD, Galluzzi L, Lucarini S, Paoletti MF, Fraternale A, Duranti A, Marco CD, Fanelli M, Zaffaroni N, Brandi G, and Magnani M: The indole-3-carbinol cyclic etrameric derivative CTet inhibits cell proliferation via overexpression of p21/CDKN1A in both estrogen receptor-positive and triplenegative breast cancer cell lines. Breast Cancer Res 13(2): R33, 2011. PMID: 21435243. DOI: $10.1186 / \mathrm{bcr} 2855$

68 Chen L, Cheng P-H, Rao X-M, McMasters K M and Zhou H S: Indole-3-carbinol (I3C) increases apoptosis, represses growth of cancer cells, and enhances adenovirus-mediated oncolysis. Cancer Biol Ther 15(9): 1256-1267, 2014. PMID: 24972095. DOI: $10.4161 / \mathrm{cbt} .29690$

69 Ouhtit A, Gaur RL, Abdraboh M, Ireland SK, Rao PN, Raj SG, Al-Riyami H, Shanmuganathan S, Gupta I, Murthy SN, Hollenbach A, and Raj MHG: Simultaneous inhibition of cellcycle, proliferation, survival, metastatic pathways and induction of apoptosis in breast cancer cells by a phytochemical supercocktail: Genes that underpin its mode of action. J Cancer 4(9): 703-715, 2013. PMID: 24312140. DOI: 10.7150/jca.7235

70 Bergin ART and Loi S: Triple negative breast cancer: recent new advances. F1000 Res 8: 1342, 2019. DOI: 10.12688/f1000research. 18888.1

71 Papadimitriou M, Mountzious G and Papadimitriou C: The role of PARP inhibition in triple-negative breast cancer: Unraveling the wide spectrum of synthetic lethality. Cancer Treat Rev 67: 34-44, 2018. PMID: 29753961. DOI: 10.1016/j.ctrv.2018.04.010

72 Greenberg S and Rugo HS: Triple-negative breast cancer: role of antiangiogenic agents. Cancer J 16(1): 33-36, 2010. PMID: 20164688. DOI: 10.1097/PPO.0b013e3181d38514

73 Costa RLB, Han HS and Gradishar WJ: Targeting the $\mathrm{PI} 3 \mathrm{~K} / \mathrm{AKT} / \mathrm{mTOR}$ pathway in triple-negative breast cancer: a review. Breast Cancer Res Treat 169(3): 397-406, 2018. PMID: 29417298. DOI: 10.1007/s10549-018-4697-y

74 Mina A, Yoder R and Sharma P: Targeting the androgen receptor in triple-negative breast cancer: current perspectives. Onco Targets Ther 10: 4675-4685, 2017. PMID: 29033586. DOI: $10.2147 /$ OTT.S126051

75 Nakhjarani M, Hardingham JE, Palethorpe HM, Price TJ and Townsend AR: Druggable molecular targets for the treatment of triple negative breast cancer. J Breast Cancer 22(3): 341-361, 2019. PMID: 31598336. DOI: 10.4048/jbc.2019.22.e39
76 Suraweera A, O’Byrne KJ and Ricard DJ: Combination therapy with histone deacetylase inhibitors (HDACi) for the treatment of cancer: Achieving the full therapeutic potential of HDACi. Front Oncol 8: 92, 2018. PMID: 29651407. DOI: 10.3389/fonc.2018. 00092

77 Ganesan A, Arimondo PB, Rots MG, Jeronimo J and Berdasco M: The timeline of epigenetic drug discovery from reality to dreams. Clin Epigenetics 11: 174, 2019. PMID: 31791394. DOI: 10.1186/s13148-019-0776-0

78 Raynal N J-M, Da Costa EM, Lee JT, Gharibyan V, Ahmed S, Zhang H, Sato T, Malouf GG, and Issa J-PJ: Repositioning FDAapproved drugs in combination with epigenetic drugs to reprogram colon cancer epigenome. Mol Cancer Ther 16(2): 397-407, 2017. PMID: 27980103. DOI: 10.1158/1535-7163.MCT-16-0588

79 Kazumi $\mathrm{H}$, Tokunaga $\mathrm{T}$, Iida $\mathrm{H}$ and Nagai $\mathrm{H}$ : Combined inhibition of ALK and HDAC induces synergistic cytotoxicity in neuroblastoma cell lines. Anticancer Res 39(7): 3579-3584, 2019. PMID: 31262882. DOI:10.21873/anticanres.13504

80 Stark K, Burger A, Wu J, Shelton P, Polin L and Li J: Reactivation of estrogen receptor $\alpha$ by vorinostat sensitizes mesenchymal-like triple-negative breast cancer to aminoflavone, a ligand of the aryl hydrocarbon receptor. PLoS One 8(9): e74525, 2013. PMID: 24058584. DOI: 10.1371/journal.pone.0074525

81 Austin D, Hamilton W, Elshimali Y, Pietras R, Wu Y and Vadgama $\mathrm{J}$ : Estrogen receptor-beta is a potential target for triple negative breast cancer treatment. Oncotarget 9(74): 33912-33930, 2018. PMID: 30338035. DOI: 10.18632/oncotarget.26089

82 Siddharth S and Sharma D: Racial disparity and triple-negative breast cancer in African-American Women: A multifaceted affair between obesity, biology, and socioeconomic determinants. Cancers 10(12): 514, 2018. PMID: 30558195. DOI: $10.3390 /$ cancers 10120514

83 Reese JM, Bruinsma ES, Nelson AW, Chernukhin I, Carroll JS, Li Y, Subramaniam M, Suman VJ, Negron V, Monroe DG, Ingle JN, Goetz MP and Hawse JR: ER $\beta$-mediated induction of cystatins results in suppression of TGF $\beta$ signaling and inhibition of triplenegative breast cancer metastasis. PNAS 115(41): E9580-E9589, 2018. PMID: 30257941. DOI: 10.1073/pnas.1807751115

84 Roca MS, Gennaro ED and Budillon A: Implications for cancer stem cells in solid cancer chemo-resistance: promising therapeutic strategies based on the use of HDAC inhibitors. J Clin Med 8(7): 912, 2019. PMID: 31247937. DOI: 10.3390/jcm8070912

Received March 10, 2020

Revised June 15, 2020

Accepted June 17, 2020 